\title{
Bicarbonate may alters bacterial susceptibility to antibiotics by targeting Pseudomonas aeruginosa, Escherichia coli and Staphylococcus aureus
}

\author{
Bikarbonat, Pseudomonas aeruginosa, Escherichia coli ve \\ Staphylococcus aureus'a karşı antibiyotiklerin duyarlılığını değiş̧irebilir
}

\author{
(D) Sevgi Kesici,, (1) Mehmet Demirci,, ${ }^{2}$ (D) Uğur Kesici \\ 'Department of Anesthesiology and Reanimation, University of Health Science, Hamidiye Etfal Training and Research Hospital, \\ İstanbul, Turkey \\ ${ }^{2}$ Department of Microbiology, Beykent University Faculty of Medicine, İstanbul, Turkey \\ ${ }^{3}$ Department of General Surgery, Beykent University Faculty of Medicine, İstanbul, Turkey
}

\begin{abstract}
Introduction: Acute acidemia is a common clinical condition in critical diseases. Acidemia is associated with poor prognosis in case of persistence. In the case of metabolic acidosis, it is beneficial to increase the $\mathrm{pH}$ by administering sodium bicarbonate $\left(\mathrm{NaHCO}_{3}\right)$ since cell functions are impaired. The aim of this study was to investigate the antibacterial efficacy of $\mathrm{NaHCO}_{3}$ used in metabolic acidosis, especially in critically ill patients in intensive care units, and to reveal its contribution to antimicrobial therapy for possible concomitant sepsis. Methods: S. aureus ATCC 29213, P. aeruginosa ATCC 27853 and E. coli ATCC 25922 strains were seeded into liquid Müller Hinton medium (Oxoid, UK) and the in-vitro effect of Group C (Control $1 \mathrm{~mL}$ sterile saline) and Group B (Sodium Bicarbonate - $\mathrm{NaHCO}_{3}$ ) on these bacteria following 24 hours of incubation at 37 degrees $C$ was investigated. Following the use of Epoch spectrophotometer (BioTek Inst. Inc. Vermont, USA) for the 0 . and 24. hours, the growth in wells was analyzed in CFU/mL and $\log 10 \mathrm{CFU} / \mathrm{mL}$ by comparison with the standard curve.

Results: From the start to the 24. hour, there was a significant decrease in bacterial colony numbers of S. aureus ATCC 29213, P. aeruginosa ATCC 27853 and E. coli ATCC 25922 strains in Group B when compared to the control group $(p<0.01)$. The intra-group antibacterial efficacy comparison revealed a significant decrease in bacterial colony numbers in Group B between $0-24$ hours $(p<0.01)$. There was a significant increase in all bacterial colony numbers in the control group $(p=0.04)$.
\end{abstract}

Özet

Amaç: Akut asidemi, kritik hastalıklarda sık görülen bir klinik durumdur. Asidemi dirençli olursa kötü prognoz ile ilişkilidir. Metabolik asidoz durumunda, hücre fonksiyonları bozulduğundan, sodyum bikarbonat $\left(\mathrm{NaHCO}_{3}\right)$ uygulayarak pH'ı artırmak yararıdır. Bu çalışmanın amacı, özellikle yoğun bakım ünitelerindeki kritik hasta hastalarda, metabolik asidozda kullanılan $\mathrm{NaHCO}_{3}$ 'ün antibakteriyel etkinliğini araştırmak ve olası eşlik eden sepsis için antimikrobiyal tedaviye katkııını ortaya koymaktır.

Gereç ve Yöntem: S. aureus ATCC 29213, P. aeruginosa ATCC 27853 ve E. coli ATCC 25922 suşları, sIVı Müller Hinton ortamına (Oxoid, UK) ekildi ve $37^{\circ} \mathrm{C}$ 'de 24 saat inkübasyonun ardından bu bakteriler üzerinde Grup C'nin (Kontrol - 1 mL steril salin), B Grubu (Sodyum Bikarbonat - NaHCO3) in vitro etkisi araştıııldı. Epoch spektrofotometresinin (BioTek Inst. Inc. Vermont, ABD) 0. ve 24. saat kullanımının ardından, kuyucuklardaki büyüme, standart eğri ile karşılaştırılarak $C F U / m L$ ve $\log 10$ CFU/mL'de analiz edildi.

Bulgular: Baştan 24. saate kadar, B grubundaki S. aureus ATCC 29213 , P. aeruginosa ATCC 27853 ve E. coli ATCC 25922 suşlarının bakteri koIoni sayııında kontrol grubuna göre anlamlı bir azalma görülmüştür $(p<0.01)$. Grup içi antibakteriyel etkinlik karşılaştırması, B grubunda bakteriyel koloni sayısında 0-24 saat arasında anlamlı bir azalma olduğu tespit edildi $(p<0.01)$. Kontrol grubundaki tüm bakteri kolonisi sayısında anlamlı bir artış vtespit edildi $(p=0,04)$.

Sonuç: Çalışmamızda $\mathrm{NaHCO}_{3}$ 'ün P. aeruginosa, E. colive S. aureus'a

Corresponding (illetişim): Uğur Kesici, Beykent Üniversitesi Tıp Fakültesi, Genel Cerrahi Anabilim Dalı, İstanbul, Turkey E-mail (E-posta): ugurkesici77@mynet.com 
Discussion and Conclusion: In our study, $\mathrm{NaHCO}_{3}$ was found to show strong antibacterial efficacy against $P$. aeruginosa, E. coli and S. aureus. Taking these results into consideration, it should be kept in mind that the use of $\mathrm{NaHCO}_{3}$ in the treatment of severe metabolic acidosis especially seen in septic patients in intensive care units will also contribute to sepsis treatment because of its antibacterial effect potential.

Keywords: Antibacterial; Escherichia coli; Pseudomonas aeruginosa; sodium bicarbonate; Staphylococcus aureus. karşı güçlü antibakteriyel etkinlik gösterdiği bulunmuştur. Bu sonuçlar göz önünde bulundurularak, özellikle yoğun bakım ünitelerinde septik hastalarda görülen şiddetli metabolik asidoz tedavisinde $\mathrm{NaHCO}_{3}$ kullanımının, antibakteriyel etki potansiyeli nedeniyle sepsis tedavisine de katkı sağlayacağı unutulmamalıdır.

Anahtar Sözcükler: Antibakteriyel; Escherichia coli; Pseudomonas aeruginosa; sodyum bikarbonat; Staphylococcus aureus.

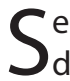
epsis is a clinical condition that causes profound neuroendocrine and metabolic changes. ${ }^{[1]}$ Severe sepsis and septic shock are common conditions associated with high hospital mortality. Nosocomial infections play a major role in the development of sepsis. ${ }^{[2]}$ Acute acidemia is also a metabolic condition that is frequently seen in critical diseases. Its incidence varies between $14 \%-42 \%$. Acidemia is associated with poor prognosis in case of persistence and may result in mortality at the rate of $57 \%$ if the $\mathrm{pH}$ value is below 7.20..$^{[3]}$

The aim of this study was to investigate the antibacterial efficacy of $\mathrm{NaHCO}_{3}$ used in metabolic acidosis, especially in critically ill patients in intensive care units, and to reveal its contribution to antimicrobial therapy for possible concomitant sepsis.

\section{Materials and Method}

S. aureus ATCC 29213, P. aeruginosa ATCC 27853 and E. coli ATCC 25922 strains were seeded into liquid Müller Hinton medium (Oxoid, UK) and the in vitro effect of Group C (Control - $1 \mathrm{~mL}$ sterile saline) and Group B (Sodium Bicarbonate - $\mathrm{NaHCO}_{3}$ ) on these bacteria following 24 hours of incubation at $370 \mathrm{C}$ was investigated. A $0.5 \mathrm{McF}$ arland turbidity standard suspension (with final measurement concentration at $106 \mathrm{CFU} / \mathrm{mL}$ ) was prepared in 2 different tubes for each strain. Group B and Group C were mixed with liquid Müller Hinton broth (Oxoid, UK) in a volume of 100 microliters. The growth in wells was analyzed in CFU/mL and $\log 10 \mathrm{CFU} / \mathrm{mL}$ by comparison with the standard curve, using OD600 (at the wavelength of 600 $\mathrm{nm}$ ) Epoch spectrophotometer (BioTek Inst. Inc. Inc. Vermont, USA) for the 0 . and 24 . hours.

\section{Statistical analysis}

SPSS Statistics 23 (IBM) package software was used for the analysis of the data in the study. Central and prevalence criteria such as number, percentage, minimum, maximum and median values were used to create descriptive statistics. The compatibility of numerical variables to normal distribution was tested visually (histogram) and analytically (Shapiro-Wilk), and Kruskal Wallis and Mann Whitney U tests were used to determine the difference between independent variables that do not conform to normal distribution. The Wilcoxon test was used to determine the difference between dependent variables that do not conform to normal distribution. A value of $p<0.05$ was accepted to be statistically significant in the study.

\section{Results}

Distribution of the amounts of $S$. aureus, $P$. aeruginosa and E. coli strains against factors at 0 . and 24 . hour $(C F U / m L)$ is shown in Table 1.

In the study, when the bacterial colony numbers of $S$. aureus ATCC 29213, P. aeruginosa ATCC 27853 and E. coli ATCC 25922 strains in the two groups were compared from the start to the 24. hour, a significant decrease was found in the colony numbers in Group B compared to the control group $(p<0.01)$. Table 2 shows the comparison of bacterial CFU differences between groups at the start and at the 24. hour.

The intra-group antibacterial activity comparison revealed a significant decrease in bacterial colony numbers in Group B between $0-24$ hours $(p<0.01)$. Maximum reduction in antibacterial activity was found to be as $P$. aeruginosa ATCC 27853> E. coli ATCC 25922> S. aureus ATCC 29213, respectively. There was a significant increase in all bacterial colony numbers in the control group $(p=0.04)$. However, there was no statistically significant difference between the bacterial species $(p=0.15)$. Table 3 and Table 4 show the comparison of the intra-group antibacterial activity for the 0.-24. hours.

Table 1. Distribution of the amounts of S. aureus, P. aeruginosa and E. coli strains against factors at 0 . and 24. hour (CFU/mL)

$$
\mathrm{CFU} / \mathrm{mL}
$$$$
\text { Group B (100 mM NaHCO })
$$

\begin{tabular}{lcc} 
& 0. hour & 24. hour \\
\hline S. aureus ATCC 29213 & 1078000 & 634340 \\
P. aeruginosa ATCC 27853 & 1166000 & 139200 \\
E. coli ATCC 25922 & 1128000 & 290800
\end{tabular}

Group C (Control)

\begin{tabular}{cc}
\hline 0. hour & 24. hour \\
1088000 & 2116000 \\
1086000 & 2248000 \\
1069600 & 2186000
\end{tabular}


Table 2. Comparison of bacterial CFU differences between groups at the start and at the 24 . hour

\begin{tabular}{|c|c|c|c|}
\hline \multirow[b]{3}{*}{$\begin{array}{l}\text { 0-24. hour } \\
\text { (CFU difference) }\end{array}$} & \multicolumn{2}{|c|}{ Group } & \multirow[b]{3}{*}{$\mathbf{p}^{*}$} \\
\hline & B & $C$ & \\
\hline & $\begin{array}{c}\text { Med. } \\
\text { (Min., Max.) }\end{array}$ & $\begin{array}{c}\text { Med. } \\
\text { (Min., Max.) }\end{array}$ & \\
\hline S. aureus & $\begin{array}{c}426 \\
(412,498)\end{array}$ & $\begin{array}{c}-1030 \\
(-1180,-890)\end{array}$ & $<0.01$ \\
\hline P. aeruginosa & $\begin{array}{c}1011 \\
(969,1075)\end{array}$ & $\begin{array}{c}-1160 \\
(-1240,-1070)\end{array}$ & $<0.01$ \\
\hline E. coli & $\begin{array}{c}839 \\
(770,908)\end{array}$ & $\begin{array}{c}-1090 \\
(-1192,-1070)\end{array}$ & $<0.01$ \\
\hline
\end{tabular}

\section{Discussion}

Sepsis is the major cause of death in patients in the intensive care unit (ICU). ${ }^{[4]}$ Nosocomial infections play a major role in the development of sepsis. ${ }^{[2]}$ Early goal-directed therapy is the standard of care. ${ }^{[5]}$ Sepsis is a complex condition characterized by the simultaneous activation of inflammation and coagulation in response to microbial agents. Today, sepsis is a severe multisystem disease with difficult treatments. Various therapeutic agents have been used in addition to antibiotherapy, but no satisfactory results have been obtained. ${ }^{[6]} \mathrm{Se}-$ vere acidemia is another clinical condition frequently seen in critically ill patients in intensive care units. $\mathrm{NaHCO}_{3}$ is used to treat severe acidemia. Specific treatment, tissue perfusion and supportive therapy are the basis for the treatment of severe metabolic acidosis in critically ill patients. Since cell functions are impaired in the case of metabolic acidosis, it is beneficial to increase the $\mathrm{pH}$ by administering sodium bicarbonate $\left(\mathrm{NaHCO}_{3}\right)_{\cdot}{ }^{[3]}$ Mitochondrial dysfunction plays an important role in the pathophysiology of sepsis and metabolic resuscitation may emerge as a new cornerstone in the treatment of sepsis. ${ }^{[4]}$ Therefore, $\mathrm{NaHCO}_{3}$, which is used especially in the treatment of metabolic acidosis, can have a significant contribution in terms of treatment efficacy and mortality due to its antibacterial efficacy as well as its role in metabolic resuscitation.

There are a limited number of studies on the antibacterial effect of $\mathrm{NaHCO}_{3}$ in the literature. ${ }^{[7]}$ Although the antibacterial efficacy of $\mathrm{NaHCO}_{3}$ has been known for many years, its mechanism of action is not clear. ${ }^{[8]}$ The study by Farha et al. ${ }^{[8]}$ showed that $\mathrm{NaHCO}_{3}$ has strong antibacterial efficacy and may have a significant impact by assisting antibiotic therapy. Consistent with this study, in our study, too, $\mathrm{NaHCO}_{3}$ was found to have a strong antibacterial effect. The study by Thompson et al. ${ }^{[7]}$ reported that $\mathrm{NaHCO}_{3}$ enhances the efficacy of lidocaine. Furthermore, the study by Begec et al..$^{[9]}$ found that, when alkalinized with $\mathrm{NaHCO}_{3}$, the antibacterial efficacy of lidocaine on S. aureus does not change while its antibacterial efficacy on $E$. coli and $P$. aeruginosa is enhanced. In our study, it was found to have antibacterial efficacy on P. aeruginosa, E. coli, S. aureus when in isolation, the weakest antibacterial efficacy being on

Table 3. Comparison of the intra-group antibacterial activity for the $\mathbf{0 . - 2 4}$. hours

\begin{tabular}{|c|c|c|c|c|}
\hline Group & \multicolumn{3}{|c|}{ 0-24. hour (CFU difference) } & $\mathbf{p}^{*}$ \\
\hline B & $426^{a}(412,498)$ & $1011^{\mathrm{b}}(969,1075)$ & $839^{\complement}(770,908)$ & $<0.01$ \\
\hline C & $1030(-1180,-890)$ & $-1160(-1240,-1070)$ & $-1090(-1192,-1070)$ & 0.15 \\
\hline
\end{tabular}

Median; Min.: Minimum; Max.: Maximum; *Kruskal Wallis Test $\mathrm{p}$ value; a, b, c: The difference between the groups shown in different letters is significant; -: Bacterium increase.

Table 4. Comparison of the intra-group antibacterial activity for the $\mathbf{0 . - 2 4}$. hours

\begin{tabular}{|c|c|c|c|c|c|}
\hline & \multicolumn{2}{|c|}{ 0. hour CFU } & \multicolumn{2}{|c|}{ 24. hour CFU } & p* $^{*}$ \\
\hline \multicolumn{6}{|l|}{ Group B $(n=5)$} \\
\hline S. aureus & 1070 & $1050 / 1140$ & 638 & $612 / 656$ & 0.04 \\
\hline P. aeruginosa & 1170 & $1090 / 1220$ & 135 & $121 / 164$ & 0.04 \\
\hline E. coli & 1120 & $1090 / 1180$ & 310 & $241 / 320$ & 0.04 \\
\hline P. aeruginosa & 1080 & $1030 / 1150$ & 2240 & $2220 / 2280$ & 0.04 \\
\hline E. coli & 1070 & $998 / 1120$ & 2190 & $2160 / 2210$ & 0.04 \\
\hline
\end{tabular}

*Wilcoxon test; Med: Median; Min.: Minimum; Max.: Maximum. 
S. aureus. According to a limited number of studies in the literature, $\mathrm{NaHCO}_{3}$ shows different levels of antibacterial efficacy concerning whether it is in isolation or in combination with other agents. However, these studies do not clearly reveal the mechanism of antibacterial efficacy of $\mathrm{NaHCO}_{3}$. The results obtained in our study and the limited results in the literature are promising in terms of the utilization of the antibacterial effect potential of $\mathrm{NaHCO}_{3}$. In our study, $\mathrm{NaHCO}_{3}$ was found to show strong antibacterial efficacy against $P$. aeruginosa, $E$. coli and $S$. aureus. Taking these results into consideration, it should be considered that the use of $\mathrm{NaHCO}_{3}$ in the treatment of severe metabolic acidosis especially seen in septic patients in intensive care units will also can contribute to sepsis treatment because of its antibacterial impact potential.

Conflict of interest: I and all authors have no conflict of interest.

\section{References}

1. Ingels C, Gunst J, Van den Berghe G.Endocrine and Metabolic Alterations in Sepsis and Implications for Treatment. Crit Care Clin 2018;34:81-96.

2. SepNet Critical Care Trials Group. Incidence of severe sepsis and septic shock in German intensive care units: the prospective, multicentre INSEP study. Intensive Care Med 2016;42:1980-9.

3. Jaber S, Paugam C, Futier E, Lefrant JY, et al. BICAR-ICU Study Group. Sodium bicarbonate therapy for patients with severe metabolic acidaemia in the intensive care unit (BICAR-ICU): a multicentre, open-label, randomised controlled, phase 3 trial. Lancet 2018 7;392:31-40.

4. Reitsema VA, Star BS, de Jager VD, van Meurs M, et al. Metabolic Resuscitation Strategies to Prevent Organ Dysfunction in Sepsis. Antioxid Redox Signal 2019 10;31:134-52.

5. Vishnupriya K, Falade O, Workneh A, Chandolu S, et al. Does sepsis treatment differ between primary and overflow intensive care units? J Hosp Med 2012;7:600-5.

6. Polat G, Ugan RA, Cadirci E, Halici Z. Sepsis and Septic Shock: Current Treatment Strategies and New Approaches. Eurasian J Med 2017;49:53-8.

7. Thompson KD, Welykyj S, Massa MC. Antibacterial activity of lidocaine in combination with a bicarbonate buffer. J Dermatol Surg Oncol 1993;19:216-20.

8. Farha MA, French S, Stokes JM, Brown ED. Bicarbonate Alters Bacterial Susceptibility to Antibiotics by Targeting the Proton Motive Force. ACS Infect Dis 2018 9;4:382-90.

9. Begec Z, Gulhas N, Toprak HI, Yetkin G, et al. Comparison of the antibacterial activity of lidocaine $1 \%$ versus alkalinized lidocaine in vitro. Curr Ther Res Clin Exp 2007;68:242-8. 